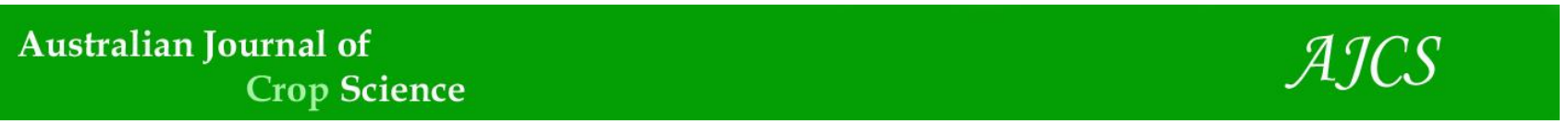

AJCS 14(11):1826-1833 (2020)

ISSN:1835-2707

doi: 10.21475/ajcs.20.14.11.p2596

\title{
Fruit and seed biometry of Carpotroche brasiliensis (RB) A. Gray (Achariaceae), a tropical tree with great potential to provide natural forest products
}

\author{
Thâmara M. Lima ${ }^{1 *}$, Elizabeth S. Amaral ${ }^{1}$, Fernanda A. Gaiotto ${ }^{1}$, Letícia dos Anjos ${ }^{2}$, Ândrea Carla Dalmolin ${ }^{3}$, \\ Alesandro Souza Santos ${ }^{1}$, Marcelo S. Mielke ${ }^{1}$ \\ ${ }^{1}$ Departamento de Ciências Biológicas, Universidade Estadual de Santa Cruz, Rodovia Jorge Amado km 16, Ilhéus, \\ BA, Brazil \\ ${ }^{2}$ Departamento de Biologia, Universidade Federal de Lavras, Av. Central, s/n - Campus Universitário, Lavras, MG, \\ Brazil \\ ${ }^{3}$ Centro de Formação em Ciências e Tecnologias Agroflrestais, Universidade Federal do Sul da Bahia Br 415 Km 22 \\ Ceplac, Ilhéus, BA, Brazil
}

*Corresponding author: thamaralima6@gmail.com

\begin{abstract}
Carpotroche brasiliensis (RB) A. Gray (Achariaceae) is a native tree species of the Brazilian Atlantic Forest with great potential provide natural forest products in agroforestry systems. The oil of its seeds contains medicinal and cosmetic properties, and the fruits are appreciated by wild animals. In this study, we analyzed the biometry of fruits and seeds collected from naturally-grown trees in agroforestry systems on small farms in southern Bahia, Brazil. Fresh fruit mass (FFM), fruit length (FL), fruit diameter (FD), number of seeds per fruit (NSF), total fresh seed mass per fruit (FSMF), total dry mass of seeds per fruit (DMSF), and mass of 1,000 seeds (MTS) were collected from 66 fruits of 18 trees on six rural properties. Seed length (SL) and seed diameter (SD) were also evaluated for 5335 seeds. From this sample universe, 697 seeds represented an adequate sample size to measure these dimensions with statistical precision. The fruits analyzed in this study had uniform values for most of the biometric variables among the sites. The average values of NSF, FFM, and MTS were approximately 88 seeds, $0.5 \mathrm{~kg}$, and $1.3 \mathrm{~kg}$, respectively. Seeds of $C$. brasiliensis obtained from freshly-harvested fruits had high water content, with an average of more than $45 \%$. Strongly significant correlations between FFM and FD and between FMSF and DMSF indicate the possibility of developing simple procedures to estimate seed production for commercial purposes from field evaluations.
\end{abstract}

Keywords: Indigenous trees, Phenotypic variability, Seed Sample Size, Network of correlation, Brazilian Atlantic Rainforest, Agroforestry systems.

\section{Introduction}

Tropical regions concentrate immense biodiversity in forest environments, conditioning the global importance of the tropics (Barlow et al., 2018). The southern coast of the state of Bahia, Brazil is recognized for its high diversity of tree species and for containing the highest percentage of tropical forest remnants of the Atlantic Forest in Northeast Brazil (Martini et al., 2007; Piotto et al., 2009). Today, southern Bahia is characterized by a mosaic landscape consisting of forest remnants and a rustic agroforestry system known as Cabruca (Sambuichi et al., 2012). Cabruca is an agroforestry system based on cacao (Theobroma cacao) cultivation under the shade of the tree strata of native forest remnants (Alvim et al., 1986; Johns, 1998). This traditional agroforestry practice has produced significant economic returns for the cocoa producers of the region (Piasentin et al., 2014). In addition to its socioeconomic importance, this system is a habitat for several species of local fauna and flora, and connects forest remnants (Cassano et al., 2011, 2016; Schroth et al., 2011). Currently, both Cabrucas and associated forest areas are threatened by the cocoa crisis (Schroth et al., 2011; Sambu- ichi et al., 2012), and there is a need for natural forest products that could potentially add value to the cocoa crop in multispecies agroforestry systems (Santos et al., 2012; Feijó et al., 2009).

The management and exploitation of native trees for natural forest products in agroforestry systems can promote biodiversity conservation and farmers' livelihoods (Rao et al., 2004; Cerda et al., 2014). Carpotroche brasiliensis (RB) A. Gray (Achariaceae) is a tree species native to the Brazilian Atlantic Forest (Schulz et al., 1994; Marquete et al., 2015). A recent study showed that this species can be grown in agroforestry systems under the shade of taller trees as well as in forest enrichment programs (Cerqueira et al., 2017). In southern Bahia, $C$. brasiliensis is frequently found in forest remnants and cabbage, and has great potential for cultivation as a natural forest products, adding value to cocoa production (Schulz et al., 1994). It is a dioecious species, with male and female flowers in different individuals. The fruits are green with an edible fleshy orange-yellow pulp, which is greatly appreciated by wild animals, mainly rodents 
(Lorenzi, 2002; Zucaratto et al., 2010). The seeds are numerous, polyhedral, with fine tests and a fleshy endosperm immersed in the pulp (Souza-Araujo, 1935). Chaulmoogra oil is extracted from the seeds, and its constituents exhibit pharmacological activities used in the treatment of leprosy and skin diseases (Souza-Araujo, 1935). The oil extracted from the seeds also has anti-inflammatory, analgesic, and anti-parasitic properties (Lima et al., 2005; Oliveira et al., 2009). The prospective income from the cultivation of $C$. brasiliensis in multispecies agroforestry systems in southern Bahia is promising (Brito-Rocha et al., 2017; Cerqueira et al., 2017). Small farmers in the region sell the fruits of this species to cosmetics companies, which use the oil in manufacturing makeup products. Despite the commercial value of the tree, its exploitation is limited to extractivism, and studies of the species are still scarce, which represents an obstacle to the production of its fruits and seeds on a larger scale. Knowledge of the biology of native species is critical for the development of in situ and ex situ conservation programs and for the development of technologies for rational agroforestry systems management (Leakey et al., 1998). For example, the fruit and seed biometry of native trees can provide important information for studies of seed ecology (Kelly, 1995; Khurana et al., 2006) and seedling establishment (Baraloto et al., 2005), and can contribute to methods of seedling production (Sautu et al., 2006; Clifton-Cardoso et al., 2008; Macedo et al., 2009). Biometric data can also be used to estimate fruit and seed production. In the context of domestication, knowledge of production can contribute to selecting beneficial genotypes and improving agronomic attributes in order to develop plantations with desirable characteristics for commercialization (Gusmão et al., 2006; Leão et al., 2018; Zuffo et al., 2019). Because it contributes to the description of phenotypic variation, biometric characterization provides vital information for the conservation and exploitation of genetic resources (Schwartz et al., 2007; Silva et al., 2017).

Given these circumstances, and considering the natural occurrence of $C$. brasiliensis in agroforestry sites in southern Bahia, the biometric characterization of its fruits and seeds will allow the evaluation of the performance of this species in the region (Botezelli et al., 2000; Menegatti et al., 2017). Determining the biometric variables of fruits and seeds can be a way of identifying useful linear relationships between variables (Maurya et al., 2015; Zuffo et al., 2016). As the seeds are of interest for propagation and are the main commercial product extracted from this tree, another potential advantage of this type of characterization is the possibility of estimating, based on statistical parameters, the number of seeds required to measure seed dimensions with statistical accuracy (Cargnelutti Filho et al., 2012; Schabarum et al., 2018). Due to the fact that many of these characteristics are relatively unknown for this species, the general objective of this study was to describe the biometry of fruits and seeds collected from plants grown naturally in agroforestry systems in small rural properties in southern Bahia, Brazil. Based on this approach, we had the following specific objectives: (i) to investigate the variation in biometric characteristics among agroforestry sites, (ii) to analyze the correlations between these biometric characteristics, and (iii) to evaluate the influence of sample size on the accuracy of seed dimension estimations.
Results

Description of the biometry of C. brasiliensis fruits and seeds in the study area

In general, fruit and seed biometry were quite similar among sites (Fig. 2). The average fruit mass was approximately 0.5 $\mathrm{kg}$. The lowest and the highest mean FFM values were found in S4 (400.8 g) and S2 (617.4 g), respectively (Fig. 2A). The lowest and highest individual values for FFM were found in S5 (114.2 g) and S2 (1065.4 g), respectively. For all sites, FL (Fig. 2B) was slightly greater than FD (Fig. 2C). The average values for $\mathrm{FL}$ and $\mathrm{FD}$ across all sites were $12.2 \mathrm{~cm}$ and 10.7 $\mathrm{cm}$, respectively. The lowest values for FL and FD were also observed in S4. Number of seeds per fruit (NSF) ranged from 71.8 (S4) to 103.3 (S3) (Fig. 2D), and the average NSF value was 88 seeds. The average FMSF and DMSF values ranged from $95.4 \mathrm{~g}$ (S1) to $127.0 \mathrm{~g}$ (S3) (Fig. 2E), and from $49.1 \mathrm{~g}$ (S1) to $66.9 \mathrm{~g}$ (S2) (Fig. 2F), respectively. The total average values for SL (Fig. 2G) and SD (Fig. 2H) were $14.1 \mathrm{~mm}$ and $11.8 \mathrm{~mm}$, respectively. The average MTS values ranged from $1,023.5 \mathrm{~g}$ (S1) to $1,576.1 \mathrm{~g}(\mathrm{~S} 2)$ (Fig. 2I), with a mean value of 1,313.4 $\mathrm{g}$ ( $\mathrm{N}=76$ fruits). This result indicates that every $1.3 \mathrm{~kg}$ of fresh C. brasiliensis seeds contains around 1,000 seeds in southern Bahia. The mean SWC (Seed water content) value was approximately $46 \%$ across all sites. Our results indicate that fruits harvested from trees in southern Bahia have a fresh weight greater than $0.8 \mathrm{~kg}$, and lengths and diameters greater than $15 \mathrm{~cm}$ and $10 \mathrm{~cm}$, respectively.

\section{Similarity of the sample sites according to the set of fruit} and seed biometric variables.

The cluster trend measure calculated using the Hopkins statistic $(H)$ showed the viability of the cluster analysis for our dataset $(\mathrm{H}=0.50)$. According to the analysis of group number, the dissimilarity among sites was equal to one (Fig. $3 A)$. In this sense, it was possible to visualize a single group among the agroforestry sites using the K-means grouping method, according to the biometric similarities of their fruits and seeds (Fig. 3B). The non-significant variation among the agroforestry sites, verified by multivariate analysis, was consistent with the results of the descriptive statistics for each biometric variable, which indicated similarity among the sites.

\section{Correlation network of biometric variables of fruits and seeds}

The network shown in Figure 4 shows the correlations between the fruit and seed biometric variables. Purple nodes represent seed variables, while yellow nodes represent fruit variables. The constructed network shows the grouping of these two types of variables. According to the thickness of the network edges, the magnitude of the correlation coefficient mainly varied for FL- SD and for FMSF- DMSF, DMSFFD, FD-FFM, and FFM-FMSF. Of the strongly positive correlations, significant correlations were observed for FMSFDMSF, FFM-FD, and NSF-FMSF. A significant negative correlation was verified for NSF-MTS. The MTS, SL, and SD variables did not present significant correlations with any other variables. 


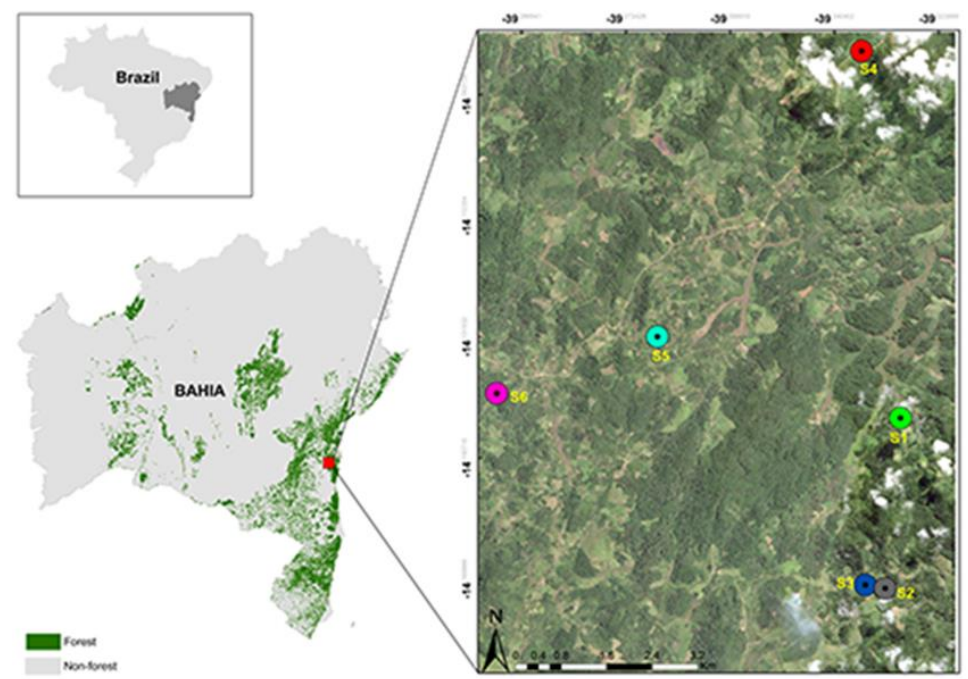

Fig 1. Map of the study area in the south of Bahia, Brazil, highlighting areas without forest (Non-Forest) and areas with forest remnants (Forest); Spatial distribution of the sampled Cabruca agroforestry sites (S1, S2, S3, S4, S5, S6).

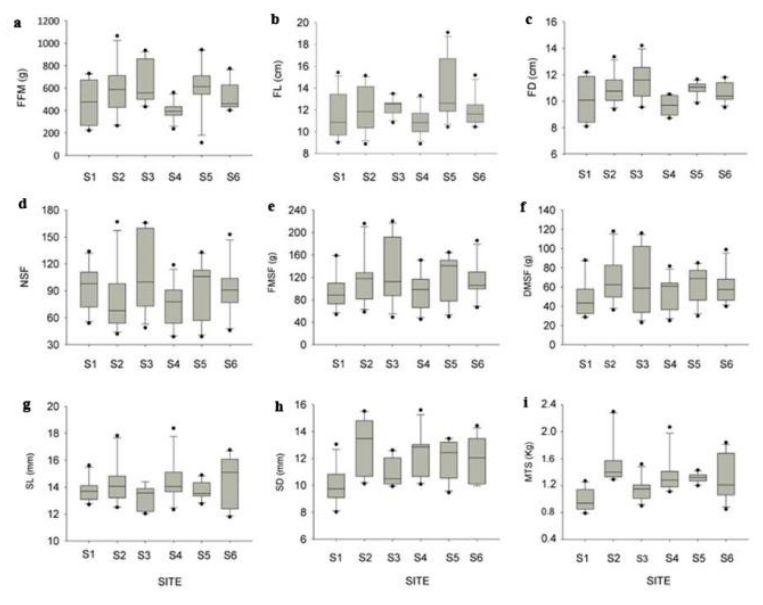

Fig 2. Fruit fresh mass (FFM) (a), fruit length (FL) (b), fruit diameter (FD) (c), number of seeds per fruit (NSF) (d), total fresh mass of seeds per fruit (FMSF) (e), dry mass of seeds per fruit (DMSF) (f), mass of 1,000 seeds (MTS) (g), seed length (SL) (h), and seed diameter (SD) (i) of $C$. brasiliensis trees from six sites in southern Bahia, Brazil. ( $n=$ three trees per site).
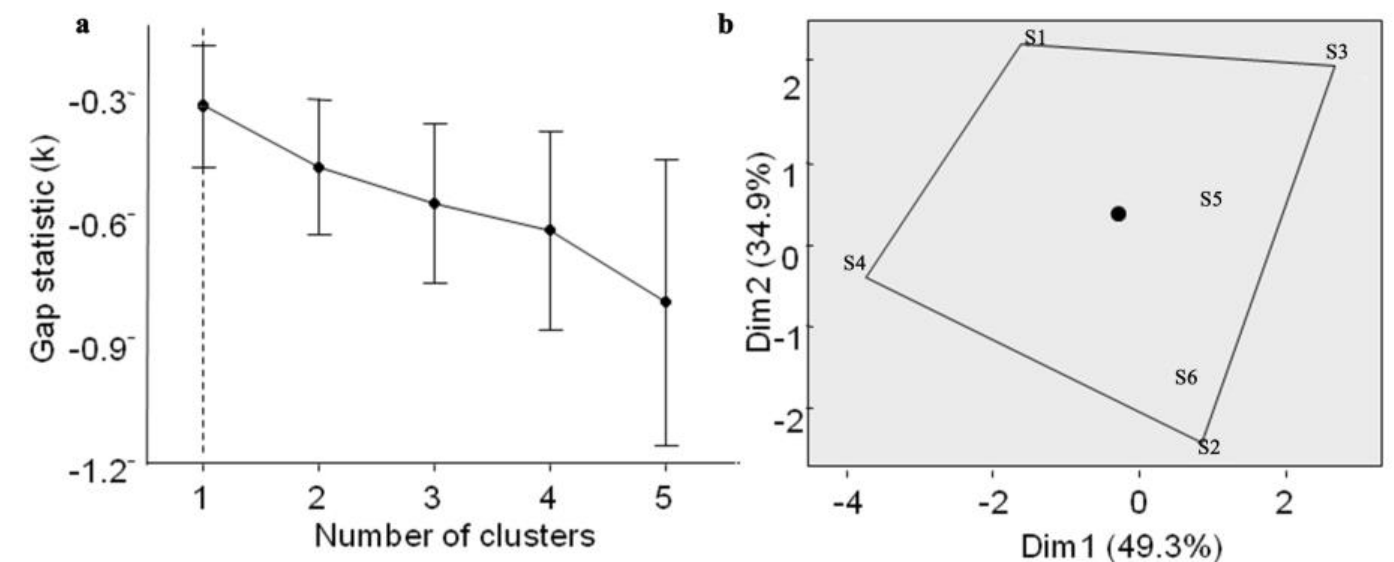

Fig 3. Number of significant groups defined for grouping (a); Clustering of agroforestry sites (S1, S2, S3, S4, S5, S6) as a function of all the biometric characteristics of $C$. brasiliensis fruits and seeds (b). 


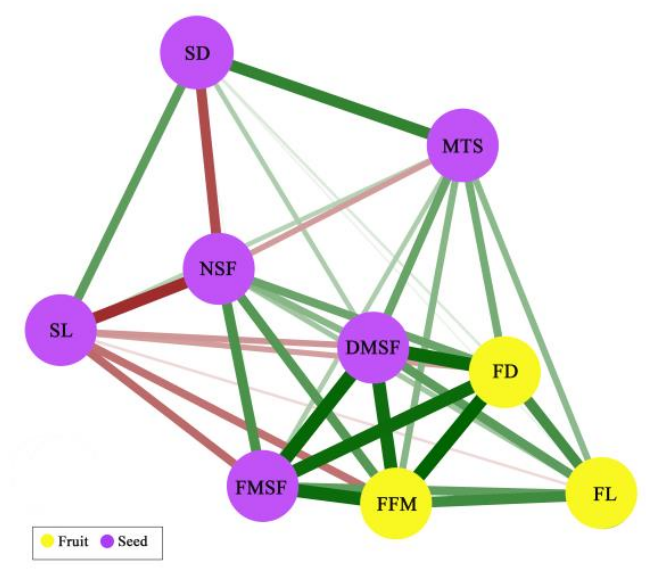

Fig 4. Pearson's correlations between network biometric variables measured in C. brasiliensis fruits at six sites in southern Bahia, Brazil. Green and red edges correspond to positive and negative correlations, respectively. The width and intensity of the edges indicate the absolute value of the correlations. Fruit fresh mass (FFM), fruit length (FL), fruit diameter (FD), number of seeds per fruit (NSF), total fresh mass of seeds per fruit (FMSF), dry mass of seeds per fruit (DMSF), mass of 1,000 seeds (MTS), seed length $(S L)$, and seed diameter (SD) ( $n=76$ fruits).
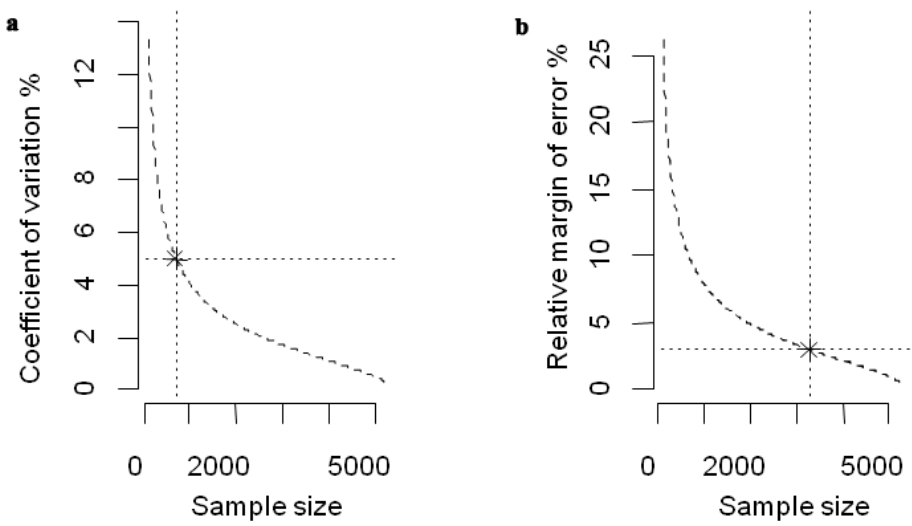

Fig 5. Sample sizes needed to minimize the coefficient of variation (a); margin of error (b).

\section{Seed sample size}

Based on the length and diameter data of 5335 seeds, an analysis that relates sample size (number of seeds) and coefficient of variation revealed that our estimates of the dimensions had good statistical accuracy. The results show that it would be necessary to measure only 697 seeds to obtain a coefficient of variation lower than 5\% (Fig. 5A). To reach a relative error rate of $3 \%$, measuring at least 3284 seeds would be sufficient (Fig. 5B).

\section{Discussion}

Given that systematic information on the biometry of $C$. brasiliensis fruits and seeds is practically non-existent, our study contributes to the enlargement of our biological knowledge of this species. To our knowledge, apart from a field survey conducted in the early twentieth century by Souza-Araujo (1935), no other research effort has been made on the biometric characterization of $C$. brasiliensis fruit and seeds to date.

The mean values of FFM, FL, and FD for all fruits in this study agree with those reported by Souza-Araujo (1935) in other regions of Brazil. Information on the mass of 1,000 seeds, such as those obtained in our research, are important for calculating the number of seeds necessary to plant in forest nurseries and in the industrial use of seeds. Foster (1982) proposed a classification system for seeds of tropical tree species based on six seed mass size-categories. According to average values obtained for MTS in this study, the fruits of $C$. brasiliensis from southern Bahia contain 634.5 to 977 seeds $\mathrm{kg}^{-1}$, which includes this species in category five of large seeds (100-1000 seeds $\mathrm{kg}^{-1}$ ) of Foster's classification. Sautu et al. (2006), using the methodology proposed by Foster (1982), conducted a study on seeds of 99 rainforest tree species in Panama. They found that only $16.2 \%$ of the species studied could be included in category five, and that $80 \%$ of the species were included in categories one to four $\left(>1,000\right.$ seeds $\left.\mathrm{kg}^{-1}\right)$. Considering the data from Sautu et al. (2006) as a comparison, we could infer that $C$. brasiliensis is within a particularly small percentage of tropical species that have large seeds. Research results of this nature represent a reliable metric for predicting the survival and growth of seedlings, especially in forest restoration areas (Baskin et al., 1998). In a tropical forest scenario with frequent and negative impacts of anthropic interventions, biological 
knowledge of tropical tree species becomes important for supporting restoration projects, particularly in the Atlantic Forest, which is a threatened tropical hotspot (Martini et al., 2007; Ribeiro et al., 2009, Barlow et al., 2016; Macera et al., 2017).

The SWC values in found this study can be considered high when compared with other tropical tree species (Walters, 2000; Sautu et al., 2006; Clifton-Cardoso et al., 2008), which may indicate that the seeds of this species are recalcitrant (Walters, 2000). Seed water content (SWC) values of around 40-50\% have been reported for other tropical rainforest tree species that lose their germination potential after desiccation, even when seeds have high SWC values (CliftonCardoso et al., 2008). Further studies are needed to investigate whether seeds of $C$. brasiliensis are recalcitrant. However, in natural forests, or when the species is grown in agroforestry systems, it is common to find broken fruits on the ground containing large number of seedlings and germinating seeds. In addition, preliminary tests made in small nurseries in southern Bahia have shown loss of seed viability after short storage periods (weeks or a few months).

Taking the results altogether, we can suggest that fruits and seeds of $C$. brasiliensis grown naturally in southern Bahia are uniform in biometry among populations in different agroforestry sites. Cabruca is an agroforestry system with unique characteristics due to its level of biodiversity of fauna and flora. These peculiarities promote important agroecological services for species productivity and stability (Johns 1998; Sambuichi et al., 2007; Schroth et al., 2007). The observed uniformity in species-seed biometry may be linked to the ability of this agroforestry system to support pollination, soil fertility, nutrient cycling, and biological control of pests and diseases (Young, 1982; Moço et al., 2009; Fontes et al., 2014; Piasentin and Saito 2014; Aleixo et al., 2017).

Correlations between fruits and seeds can help us to understand the dynamics of the inherent relationships between the characteristics of each species (Gonçalves et al., 2013; Souza et al., 2016; Maurya et al., 2015; Zuffo et al., 2016). The network correlation analysis performed in our study allowed the visualization of correlations and binding patterns that are difficult to detect in numerical correlation matrices (Epskamp et al., 2012). This knowledge is vital for the domestication of wild species, as is the case in our biological model of study (Silva et al., 2016). Significantly strong correlations between FFM-FD and FMSF-DMSF indicate that it is possible to develop procedures to estimate seed production for commercial purposes from field evaluations. The strategy of selecting more productive genotypes through variables that can be easily obtained in the field is an efficient tool for improving commercial production (Nietsche et al., 2015).

Considering that the potential harvest from $C$. brasiliensis in agroforestry systems is mainly the seeds, which also represent the propagation structure, our study provided knowledge that may help to subsidize the efficiency of the use of this species. In addition to what has already been discussed regarding the seeds, another important approach is the ideal sample size in the context of biometric characterization. For native trees such as $C$. brasiliensis, irregular seed production may hinder robust sampling. The greater the sample size used to estimate variables, the lower the coefficient of variation and, consequently, the lower the error estimate (Searls, 1964; Kelley, 2007). The estimated seed size in our study was established through a large sample size (5335 seeds measured). As a smaller number of seeds than that evaluated would already be sufficient to obtain good precision, adjusting the sample size according to statistical parameters contributes to the efficiency of robust results (Schabarum et al., 2018), mainly for native trees.

\section{Materials and methods}

\section{Plant materials}

The fruits were collected from spontaneously-growing trees in six small-farm sites (S1-S6) following the Cabruca agroforest system in the municipalities of Camamú and Maraú, Bahia, Brazil. A heterogeneous landscape mosaic map of the study area was created using ArcGis (10.2) (Figure 1). The fruits were collected between September and November 2013.

\section{Traits measured}

Fruit fresh mass (FFM), fruit length (FL), fruit diameter (FD), number of seeds per fruit (NSF), total fresh mass of seeds per fruit (FMSF), total dry mass of seeds per fruit (DMSF), and mass of 1,000 seeds (MTS) were measured from 66 fruits of 18 trees. The protocols of the International Seed Testing Association (Ista, 1993) and the rules of the Brazilian Ministry of Agriculture and Food Supplies for seed analysis (Mapa, 2009) recommend that MTS should be determined for eight replicates of 100 seeds. In our study, MTS was calculated from the average of 76 fruits with approximately 88 seeds each. In total, we evaluated 5335 seeds, which provided a good measure of the mass of 1,000 seeds for the species in southern Bahia. Seed length (SL) and seed diameter (SD) were evaluated using a digital caliper. Total dry mass of seeds per fruit (DMSF) was obtained after drying the leaves at $75^{\circ} \mathrm{C}$ until a constant mass was reached. Mass of 1,000 seeds (MTS) was calculated using the following equation: $\mathrm{MTS}=(1000 \times \mathrm{FMSF}) / \mathrm{NSF}$. The water content of the seeds (SWC) was calculated as $S W C=\frac{F M S F-D M S F}{100} * F M S$

\section{Statistical analysis}

The data were evaluated separately based on 11 fruits per site. The descriptive statistics of the biometric characteristics are represented by boxplot graphs. Pearson correlation was estimated between the variables studied through a correlation network. The correlation network analysis was based on the Fruchterman-Reingold algorithm (Fruchterman et al., 1991), which shows the proximity between nodes by the absolute value of the correlation between these nodes (Epskamp et al., 2012). Each node represents a variable, and each edge represents a correlation between two variables. The 'qgraph' package (Epskamp et al., 2012) in R was used to carry out the network analysis. The significance of the Pearson correlation coefficients was estimated by Student's ttests at a $5 \%$ probability level. To analyze the similarities between the sites (S1-S6), a multivariate analysis was performed using the K-means non-hierarchical clustering method (Macqueen, 1967). It is noteworthy that before choosing a clustering approach, Hopkins statistic $(\mathrm{H})$ was performed to evaluate the clustering trend (Banerjee et al., 2004). The analysis was performed based on the number of groups defined by the clusgap function and on clustering by the hkmeans function of the 'cluster' and 'factoextra' packages in $R$, respectively (Tibshirani et al., 2001). In addition, the 'samples4' package was used to estimate the appropriate 
sample size according to the coefficient of variation (Gutiérrez et al., 2016). All statistical analyses were completing in the $R$ version 3.5.3 programming software ( $R$ Development Core Team, 2019).

\section{Conclusions}

This study provided the biometric characterization of $C$. brasiliensis fruits and seeds in southern Bahia, Brazil. Relatively unknown data on the biometric attributes of this species indicate the importance of our study in developing strategies for the seeds of the species to be used as a potential natural forest products. The lack of variation among agroforestry sites indicates a process of incipient domestication of this tree. The fact that the oil extracted from $C$. brasiliensis seeds is valuable as a commercial product probably did not allow selection intensity to affect variation among sites. Our study also estimated the number of seeds suitable for biometric characterization. We emphasize the importance of this particular analysis in establishing a suitable degree of statistical confidence in research on forest species that usually produce a smaller seed sample size than agricultural species.

\section{Acknowledgments}

This study was supported by Natura Inovação e Tecnologia de Produtos LTDA. We thank Gerson J. Sales Neto, Nilson A. dos Santos, and Rones F. Souza, of Floresta Viva Institute, and Meide Fernando B. Santana for assistance with data collection. We also acknowledge the farmers of the municipalities of Camamu and Maraú, southern Bahia, Brazil, for consent the collection of fruits in their properties. FAG and MSM gratefully acknowledge productivity fellowship provided by CNPq (Brazilian National Council for Scientific and Technological Development). TML acknowledges CAPES for her Ph.D. scholarship.

\section{References}

Aleixo S, Gama-Rodrigues AC, Costa MG, Sales MVS, GamaRodrigues EF, Marques JRB (2017) P transformations in cacao agroforests soils in the Atlantic forest region of $\mathrm{Ba}$ hia, Brazil. Agroforest Syst. 91(3):423-437.

Alvim R, Nair PKR (1986) Combination of cacao with other plantation crops: an agroforestry system in Southeast Bahia, Brazil. Agroforest Syst. 4(1):3-15.

Banerjee A, Davé RN (2004) Validating clusters using the Hopkins statistic. IEEE Int Conf Fuzzy Syst. 1(4):149-153.

Baraloto C, Forget PM, Goldberg DE (2005) Seed mass, seedling size and neotropical tree seedling establishment. J Ecol. 93(6):1156-1166.

Barlow J, Lennox GD, Ferreira J, Berenguer E, Lees AC, Nally RM, Thomson JR, Ferraz SFB, Louzada J, Oiveira VHF, Parry L, Solar RRC, Vieira ICG, Aragão LEOC, Begotti RA, Braga RF, Cardoso TM, Oliveira RC, Souza CM, Moura NG, Nunes SS, Siqueira JV, Pardini R, Silveira JM, Vaz-de-Mello FZ, Veiga RCS, Venturini A, Gardner TA (2016) Anthropogenic disturbance in tropical forests can double biodiversity loss from deforestation. Nature. 535(7610):144-147.

Barlow J, França F, Gardner TA, Hicks CC, Lennox GD, Berenguer $E$, Castello L, Economo EP, Ferreira J, Guénard B, Leal CG, Isaac V, Lees AC, Parr CL, Wilson SK, Young PL, Graham NAJ (2018) The future of hyperdiverse tropical ecosystems. Nature. 559 (7715):517-526.
Baskin CC, Baskin JM (1998) Seeds: ecology, biogeography, and, evolution of dormancy and germination. Elsevier.

Botezelli L, Claudio A, Malavasi MM (2000) Características dos frutos e sementes de quatro procedências de Dipteryx alata Vogel (Baru). Rev Cern. 6(1):9-18

Brito-Rocha E, dos Anjos L, Schilling AC, Dalmolin AC, Mielke MS (2017) Individual leaf area estimations of a dioecious tropical tree species Carpotroche brasiliensis (Raddi) A. Gray, Achariaceae. Agroforest Syst. 91(1):9-15.

Cargnelutti Filho A, Toebe M, Facco G (2012) Tamanho de amostra para a estimação da média do comprimento, diâmetro e massa de sementes de feijão de porco e mucuna cinza. Ciência Rural. 42(9):1541-1544.

Cassano CR, Kierulff MCM, Chiarello AG (2011) The cacao agroforests of the Brazilian Atlantic forest as habitat for the endangered maned sloth Bradypus torquatus. Mamm Biol. 76:243-250.

Cassano CR, Silva RM, Mariano-Neto E, Schrothc G, Faria D (2016) Bat and bird exclusion but not shade cover influence arthropod abundance and cocoa leaf consumption in agroforestry landscape in northeast Brazil. Agric Ecosyst Environ. 232(9):247-253.

Cerda R, Deheuvels O, Calvache D, Niehaus L, Saenz Y, Kent J, Vilchez S, Villota A, Martinez C, Somarriba E (2014) Contribution of cocoa agroforestry systems to family income and domestic consumption: looking toward intensification. Agroforest Syst. 88(6):957-981.

Cerqueira AF, Dalmolin ÂC, dos Anjos L, Ledo CAS, Silva DC, Mielke MS (2017) Photosynthetic plasticity of young plants of Carpotroche brasiliensis (Raddi) A. Gray, Achariaceae. Trees. 32(1):191-202.

Clifton-Cardoso BC, Mielke MS, De Melo JR, Querino RN (2008) Germination and seedling growth of Dimorphandra jorgei MF Silva and Swartzia macrostachya Benth. var. riedelii Cowan. New For. 35(1):15-31.

Epskamp S, Cramer AOJ, Waldorp LJ, Schmittmann VD, Borsboom D (2012) qgraph: Network Visualizations of Relationships in Psychometric Data. J Stat Softw 48 (4): 1-18.

Feijó NSA, Mielke MS, Gomes FP, França S, Lavinsky AO (2009) Growth and photosynthetic responses of Gallesia integrifolia (Spreng.) Harms and Schinus terebinthifolius Raddi seedlings in dense shade. Agroforest Syst. 77(1):4958.

Fontes AG, Gama-Rodrigues AC, Gama-Rodrigues EF, Sales MVS, Costa MG, Machado RCR (2014) Nutrient stocks in litterfall and litter in cocoa agroforests in Brazil. Plant Soil. 383(2):313-335.

Foster SA, Janson CH (1985) The Relationship between Seed Size and Establishment Conditions in Tropical Woody Plants Author(s): Susan Foster and Charles H. Janson Source: Ecology. 66(3):773-780.

Gonçalves LGV, Ribeiro Andrade F, Hur B, Schossler TR, Lenza E, Marimon BS (2013) Biometria de frutos e sementes de mangaba (Hancornia speciosa Gomes) em vegetação natural na região leste de Mato Grosso, Brasil. Rev Ciências Agrárias.36(1):31-40.

Gusmão E, Vieira F de A, Júnior ÉMF (2006) Biometria de frutos e endocarpos de Murici (Byrsonima verbascifolia Rich. ex A. Juss. Cern Lavras. 12(1):84-91.

Gutiérrez A, Zhang H, Montaño C (2016) Sample size for the estimation of a finite population variance with $R$ functions. Comun en Estadística Stat Eval Educ. 9(1):99-116

International Seed Testing Association ISTA (1993) International Rules for Seed Testing International Seed Testing Association, Zürich, Switzerland 
Johns ND (1998) Conservation in Brazil's chocolate forest: The unlikely persistence of the traditional cocoa agroecosystem. Environ Manage 23(1):31-47.

Kelly CK (1995) Seed size in tropical trees: a comparative study of factors affecting seed size in Peruvian angiosperms. Oecologia.102(3):377-388.

Kelley K (2007) Sample size planning for the coefficient of variation from the accuracy in. Behav Res Methods. 39(4):755-766.

Khurana E, Sagar R, Singh JS (2006) Seed size: a key trait determining species distribution and diversity of dry tropical forest in northern India. Acta Oecologica. 29(2):196204.

Leakey R, Simons A (1998) The domestication and commercialization of indigenous trees in agroforestry for the alleviation of poverty. Agroforest Syst. 38(1):165-176.

Leão NVM, Felipe SHS, Silva CE, Moraes ACS, Shimizu ESC, Gallo $R$, Freitas ADD, Kato OR (2018) Morphometric diversity between fruits and seeds of mahogany trees (Swietenia macrophylla King.) from Parakanã Indigenous Land, Pará State, Brazil. Australian Journal of Crop Science. 12(3):435-443.

Lima JA, Oliveira AS, de Miranda ALP, Rezende CM, Pinto AC (2005) Anti-inflammatory and antinociceptive activities of an acid fraction of the seeds of Carpotroche brasiliensis (Raddi) (Flacourtiaceae). Brazilian J Med Biol Res. 38(1):1095-1103.

Lorenzi H, Matos FJA (2002) Plantas medicinais no Brasil: Nativas e Exóticas. Instituto Plantarum, Nova Odessa.

Macedo MC de, Scalon S de PQ, Sari AP, Scalon Filho H, Rosa YBCJ, Robaina AD (2009) Biometria de frutos e sementes e germinação de Magonia pubescens ST.Hil (Sapindaceae). Rev Bras Sementes. 31(2):202-211.

Macera LG, Pereira SR, Souza ALT (2017) Survival and growth of tree seedlings as a function of seed size in a gallery forest under restoration. Acta Bot Brasilica. 31(4):539-545.

MacQueen JB (1967) Some methods for classification and analysis of multivariate observations. Proceedings of the 5th Berkeley Symposium on Mathematical Statistics and Probability. 38(1): 281-297.

Mapa (2009) Regras para análise de sementes. Ministério da Agricultura, Pecuária e Abastecimento, Brasília.

Marquete R, Torres RB, Medeiros ES (2015) Achariaceae. In: Lista de Espécies da Flora do Brasil. Jardim Botânico do Rio de Janeiro

http://floradobrasil.jbri.gov.br/jabot/floradobrasil/FB34

Martini AMZ, Fiaschi P, Amorim AM, Paixão JL (2007) A hotpoint within a hot-spot: A high diversity site in Brazil's Atlantic Forest. Biodivers Conserv 16(5):3111-3128.

Maurya R, Kumar U, Katiyar R, Yadav HK (2015) Correlation and path coefficient analysis in Jatropha curcas L. Genetika.47(1):63-70.

Menegatti RD, Mantovani A, Navroski MC, Souza GA (2017) Genetic divergence among provenances of Mimosa scabrella Benth. Based on seed analysis. Rev Bras Ciencias Agrar. 12(3):366-371.

Moço MK, Da Gama-Rodrigues EF, Da Gama-Rodrigues AC, Machado RCR, Baligar VC (2008) Soil and litter fauna of cacao agroforestry systems in Bahia, Brazil. Agroforest Syst.76(1):127-138.

Nietsche S, Vendrame WA, Crane JH, Pereira MCT, Costa A, Reis ST (2015) Variability in reproductive traits in Jatropha curcas L. accessions during early developmental stages under warm subtropical conditions. GCB Bioenergy.7(1):122-134.
Oliveira AS, Lima JA, Rezende CM, Pinto AC (2009) Ácidos ciclopentênicos do óleo da sapucainha (Carpotroche brasiliensis endl, Flacourtiaceae): o primeiro antileprótico usado no Brasil. Quim Nov. 32(1):139-145.

Piasentin FB, Saito CH (2014) The different methods of cocoa farming in southeastern Bahia, Brazil: historical aspects and perceptions. Bol do Mus Para Emílio Goeldi Ciências Humanas.9(1):61-78.

Piotto D, Montagnini F, Thomas W, Ashton M, Oliver C (2009) Forest recovery after swidden cultivation across a 40 -year chronosequence in the Atlantic forest of southern Bahia, Brazil. Plant Ecol. 205(2):261-272.

R Core Team R (2019) A language and environment for statistical computing. R Foundation for Statistical Computing, Vienna, Austria. URL https://www.R-project.org/

Rao MR, Palada M, Becker B (2004) Medicinal and aromatic plants in agroforestry systems. Agroforest Syst. 61(1):107122

Ribeiro MC, Metzger JP, Martensen AC, Ponzoni FJ, Hirota MM (2009) The Brazilian Atlantic Forest: How much is left, and how is the remaining forest distributed? Implications for conservation. Biol Conserv.142(6):1141-1153.

Sambuichi RHR, Haridasan M (2007) Recovery of species richness and conservation of native Atlantic forest trees in the cacao plantations of southern Bahia in Brazil. Biodivers Conserv.16(13):3681-3701.

Sambuichi RHR, Vidal DB, Piasentin FB, Jardim JG, Viana TG, Menezes AA, Mello DLN, Ahnert D, Baligar VC (2012) Cabruca agroforests in southern Bahia, Brazil: Tree component, management practices and tree species conservation. Biodivers Conserv.21(4):1055-1077.

Santos MLS, França S, Gomes FP, Nascimento J (2012) Low light availability affects leaf gas exchange, growth and survival of Euterpe edulis seedlings transplanted into the understory of an anthropic tropical rainforest. South For.74(3):167-174.

Sautu A, Baskin JM, Baskin CC, Condit R (2006) Studies on the seed biology of 100 native species of trees in a seasonal moist tropical forest, Panama, Central America. For Ecol Manage.234(3):245-263.

Schabarum DE, Filho AC, Lavezo A, Follmann D (2018) Sample Size for Morphological Traits of Sunn Hemp Denison. J Agric Sci. 10(1):152-161.

Schroth G, Faria D, Araujo M, Bede L, Bael SAV, Cassano CR, Oliveira LC, Delabie JHC (2011) Conservation in tropical landscape mosaics: The case of the cacao landscape of southern Bahia, Brazil. Biodivers Conserv. 20(8):16351654.

Schulz B, Becker B, Götsch E (1994) Indigenous knowledge in a "modern" sustainable agroforestry system-a case study from eastern Brazil. Agrofor Syst.25(1):59-69.

Schwartz E, Barbieri RLÍA, Baptista J, Silva DA (2007) Avaliação de populações de Butia capitata de Santa Vitória do Palmar. Rev Bras Frutic.32(3):736-745

Searls DT (1964) The Utilization of a Known Coefficient of Variation in the Estimation Procedure. J Am Stat Assoc. 59(308):1225-1226.

Silva AR, Rêgo ER, Pessoa AMS, Rêgo MM (2016) Correlation network analysis between phenotypic and genotypic traits of chili pepper. Pesqui Agropecuária Bras.51(4):372-377.

Silva BM, Rossi AAB, Dardengo JDFE, Tiago PV, Silveira GF, Souza SAM (2017) Genetic divergences between Spondias mombin (Anacardiaceae) genotypes found through morphological traits. Rev Biol Trop. 65(6):1337.

Somarriba E, Cerda R, Orozco L, Cifuentes M (2013) Carbon 
stocks and cocoa yields in agroforestry systems of Central America. Agric Ecosyst Environ. 173(6):46-57.

Souza-Araujo HC (1935) The Brazilian Chaulmoogra: Carpotroche brasiliensis. Int J Lepr. 49-77.

Souza AG, Smiderle OJ, Spinelli VM, Souza RO, Bianchi VJ (2016) Correlation of biometrical characteristics of fruit and seed with twinning and vigor of Prunus persica rootstocks. J Seed Sci.38(4):322-328.

Tibshirani R, Walther G, Hastie T (2001) Estimating the number of clusters in a data set via the gap statistic. J R Stat Soc Ser B Stat Methodol.63(2):411-423.

Young AM (1982) Effects of Shade Cover and Availability of Midge Breeding Sites on Pollinating Midge Populations and Fruit Set in Two Cocoa Farms. J Appl Ecol. 19(1):47.

Zucaratto R, Carrara R, Siqueira BK (2010) Dieta da paca
(Cuniculus paca) usando métodos indiretos numa área de cultura agrícola na Floresta Atlântica brasileira. Biotemas.23(1):235-239.

Zuffo AM, Bush A, Zuffo-Júnior JM (2016) Physical characterization of fruits and seeds of ( Fabaceae) Delonix regia ( bojer ex hook .) raf . ( fabaceae - caesalpinoideae). Int J Curr Res. 8(1):42072-42076.

Zuffo AM, Busch A, Steiner F, Alves CZ, Neto FA, Santos MA, Nogueira GA, Fonseca WL, Oliveira AM, Sousa TO, Santos AS (2019) Biometric characteristics of fruits, seeds and plants of Hancornia speciosa Gomes. (Apocynaceae). Australian Journal of Crop Science. 13(4):622-627.

Walters C (2000) Levels of recalcitrance in seeds. Braz J Plant Physiol.12:7-21. 